\title{
DETERMINANTS OF ACADEMIC YOUTH'S ATTITUDES TOWARDS THE IDEA OF SUSTAINABLE DEVELOPMENT
}

Aleksandra Plonka', Phd Eng.; Mariusz Dacko², Phd Eng.

1,2 University of Agriculture in Krakow

\begin{abstract}
The paper presents findings of a study conducted among academic youth in over 30 European countries. The aim of the study was to find out students' opinions and attitudes towards the idea of sustainable development. Respondents' responses to the question concerning living in accordance with the principles of sustainable development have been analysed. When considering the variations in the answers provided to this question, attention was paid to the youth's nationality, which was generalised by grouping their home countries into three categories: $\mathrm{EU}_{15}, \mathrm{EU}_{28-15}$, outside of the $\mathrm{EU}$. It has also been examined whether the variation in the responses was impacted by the level of education as declared in the survey section containing respondents' sociodemographic data, i.e. first-, second- or third-cycle studies. Variation in the responses by gender as well as by respondents' background and place of residence, i.e. city or rural area, has also been addressed. The data were obtained by means of a survey questionnaire developed in the English language and processed using pivot tables prepared in Microsoft Excel spreadsheet.
\end{abstract}

Key words: sustainable development, students' attitudes, surveys.

JEL code: Q56.

\section{Introduction}

The concept of sustainable development has for almost five decades been a subject of an in-depth analysis by commentators and representatives of scientific circles, becoming a domain of studies, discussions and exchange of opinions. The subject of sustainable development enjoys great popularity, although the popularity of this term has exceeded its significance and practical effectiveness (Boc J. et al., 2004). Over years, new views have appeared on the idea of sustainable development and its role in shaping social attitudes. Many scholars even raise it in their works to the level of a modern paradigm (Borys T., 2011; Poskrobko B., 2013; Matysiak A., Strus M., 2015; Poczta-Wajda A., Sapa A., 2017).

In general terms, the philosophy of sustainable development boils down to combining two concepts: "growth" and "development" into a compatible whole. Based on discussion by Hulla (1992), it can be assumed that "growth" is a quantitative increase in matter (in the economy increase in goods and services), whereas "development" is a process of quantitative and qualitative transformations of such matter (in the economy - enabling extension of the existing possibilities or taking advantage of new ones). As an attempt to reconcile both these aspects, the concept of sustainable development proposes a qualitatively new form of a conscious, responsible individual and social life where development is adjusted to the environment - social and natural - taking into account ecological limitations and social expectations (Skowronski A., 2006). It encompasses management of natural, economic and human resources, spatial management, institutional solutions, moral sphere, and building of awareness leading to choosing a specific model of life (Piontek B., 2002). In essence, this concept formulates a new, environmentally optimal and socially satisfactory vision of the development of civilisation (Skowronski A., 2006) which however requires the society to

\footnotetext{
${ }^{1}$ Aleksandra Płonka PhD Eng.; The University of Agriculture in Krakow, Poland

The Faculty of Agriculture and Economics, the Institute of Economic and Social Sciences, the Department of Economics and Organization of Agriculture

e-mail: a.plonka@ur.krakow.pl (corresponding author)

2 Mariusz Dacko PhD Eng.; The University of Agriculture in Krakow, Poland

The Faculty of Agriculture and Economics, the Institute of Economic and Social Sciences, the Department of Economics and Organization of Agriculture,

e-mail: m.dacko@ur.krakow.p
} 
understand and shape desirable relationships between the environment, economy and society (Dacko M., Plonka A., 2017).

In order to shape social behaviours consistent with the postulate of intergenerational justice, during the 1992 UN Conference "Environment and Development" in Rio de Janeiro it was agreed under Global Plan of Actions Agenda 21 that there was a need for providing education for sustainable development as part of curricula of all subjects at all levels of the education system. "Strategy of Education for Sustainable Development" of the UN European Economic Commission (2008) was developed highlighting the need to incorporate the principles of education for sustainable development into education systems. The importance of this issue was also stressed during the sustainable development agenda summit held at the United Nations' headquarters in New York in 2015. During the meeting, the document Sustainable Development Agenda 2030 was adopted indicating the provision of inclusive and high-quality education for sustainable development to global society as one of the key objectives of sustainable development. It was agreed that the established international arrangements would be reflected in strategic policies and documents of the individual countries (Agenda..., 2015).

In Poland the principle of sustainable development was raised to the constitutional level and by way of the Act Environmental Law of 2001 an obligation was introduced to include the issues of sustainable development in core curricula of general education for all types of schools (Act Environmental Law..., 2001). However, it seems that the provisions of the act are still not reflected in the curricula adopted in education of Polish youth. An expert report on education for sustainable development in Poland eleven years later showed that the definition of sustainable development was difficult to understand for the society, and the guidelines on introducing education for sustainable development in schools, including in particular in universities, were very general and only applied to certain fields of studies (Ekspertyza... 2012). According to Lorek (2013), the present system of higher education is characterised by an approach focused on narrow specialisations and isolation of the different scientific fields. The curricula often show an incorrect tendency to address economic, social and environmental aspects of sustainable development separately (Lorek A., 2013). Cases of implementing a comprehensive educational programme reflecting the principles of sustainable development are still rare, and the issues of the natural environment have for years been overlooked and ignored in teaching and economic research, which makes it difficult to manage the relationships between the economy and the environment (Kielczewski D., Poskrobko T., 2009; Kielczewski D., Poskrobko T., 2010). Against this background, it makes sense to consider the research problem/question posed by the authors of this work: what are the attitudes of European academic youth towards sustainable development and what determines the differences in these attitudes.

\section{Material and the research method}

In order to find the answer to the research problems adopted in this work, extensive research was conducted among a group of 1054 respondents, i.e. academic youth from over 30 European countries. The main research tool was an original survey questionnaire directed at students, prepared in the English language and containing sets of questions concerning, among other things, the interpretation of sustainable development, living in accordance with its principles, and individual actions taken by respondents to implement this idea. The questions contained in the questionnaire were both open-ended and close-ended. An overwhelming majority of them was obligatory, meaning that the respondent was not allowed to skip a question by failing to provide an answer to it. For 
close-ended questions, a set of possible responses was provided, with their number depending on the type (content) of the question. Focusing on the key research aspects concerning academic youth's attitudes towards the idea of sustainable development as addressed in this paper, each respondent was asked, among other things, whether they try to live in accordance with the principles of sustainable development. As a response to the questions, 5 possible options, ordered on a descending scale, were provided: definitely yes, rather yes, neither yes nor no, rather not, definitely not and one answer indicating lack of knowledge or opinion, i.e. I have No opinion. The issues were examined in terms of adopted determinants, i.e. by the group of European countries to which students belonged, level of education, background and place of residence as well as the gender criterion.

The research was conducted from April 2017 to January 2018. During the 9 months, the questionnaire was filled out by 754 respondents from EU countries and 300 people from outside of the EU. As the respondents represented various European countries, they were divided into three key groups, and then their responses were analysed to see if there were any variations between these groups. The group that for the purpose of this research was called "countries outside of the EU" numbered 300 respondents, mainly from Ukraine, Russia, Belarus, Turkey and Serbia. The "EU 15 countries" group included responses given by 103 representatives of academic youth from 15 countries of the so-called "old" European Union (with mostly students from Belgium, Finland, Germany, Spain and Sweden). The group that for the purpose of this research was called "EU $28-15$ countries" or "new countries of the EU" included 234 students from countries that joined the European Union as part of 2004, 2007 and 2013 accessions (strongly represented especially by students from Lithuania, Latvia, Estonia, Hungary and Slovakia).

Due to the spatial coverage of the research, it was conducted exclusively in an electronic form, and the respondents were provided with a link to the survey questionnaire on Google Drive. Owing to the kindness and help of many lecturers from various academic facilities (both in the country and abroad), the survey questionnaire was spread among a large group of students. Many responses were obtained as a result of posting the questionnaire at the website homepage of a network of universities and other higher education institutions located in the region of the Baltic See, associated in the international network the Baltic University Programme. This organisation is focused on issues connected with sustainable development, both in the educational, scientific and practical aspects (Dacko M. et al., 2018). Given the above, the findings of the research were not only assessed as satisfactory, but they also entitled the authors to make certain generalisations, although the sampling was not strictly random, but governed by the methods of "attaching and capturing on the way" known from the practice of marketing research (Kowal J., 1998).

\section{Research results and discussion}

The awareness of and social attitudes towards the idea of sustainable development among European youth may depend not only on EU membership, but also on how long the different countries have been functioning within EU structures. Following successive accessions, which took place in 1973, 1981, 1986, 1995, 2004, 2007 and 2013, 28 out of 46 European countries function in the European Community. The critical year was 2004, when the Community opened up on a wide scale to the economies of Central and Eastern Europe, accepting as many as 10 new states as its members. It can be assumed that the awareness of and attitudes towards sustainable development may not have been shaped and established so well in the societies of the new member states (with completely 
different socio-economic conditions) as in the $\mathrm{EU}_{15}$ countries. Already a few decades ago, the countries of the so-called "old Union" noted that the condition of the environment in the Community depended not only on the developments on its territory, but increasingly on actions taken by third countries. For that reason, the growing European Community became over the years an initiator and an increasingly active participant of international conventions, agreements and arrangements concerning environmental protection and sustainable development. It is worth reminding that as early as in 1973 the first long-term Community Environment Action Programme was developed, with other such programmes (second, third and fourth) successively launched in 1976, 1982 and 1987. Their environmental postulates provide a basis for implementation of future actions in all areas of an environmental policy. As part of horizontal strategies and international negotiations on the environment, they have directly referred since the 1990s (fifth, sixth and seventh programme) to the idea of sustainable development, which became the leading issue in shaping socio-economic order. Given the above, it can be assumed that the awareness of and social attitudes towards sustainable development in European countries functioning outside of the European Community may have been shaped differently.

These assumptions were confirmed in the research findings. Living in accordance with the principles of sustainable development was most often declared by academic youth from the $\mathrm{EU}_{15}$ countries. In this group, as many as two thirds of the respondents gave a positive answer: "definitely yes" and "rather yes" (Table 1). Compared to the other groups of respondents, the shares of those indifferent $(21.4 \%)$ and without an opinion ( $5.8 \%)$ were the lowest. It is also worth noting that No one in this group assessed their life as being in stark contrast to the principles of sustainable development. Interesting was the distribution of answers provided by representatives of the other two groups. Living in accordance with the principles of sustainable development was relatively more often declared by students from countries outside of the EU than the countries that have joined it since 2004 (Dacko M. et al., 2018). Although the percentage of negative answers ("rather not" and "definitely not") was higher outside of the $\mathrm{EU}$, respondents from the $\mathrm{UE}_{28-15}$ countries relatively more often expressed their indifference towards the principles of sustainable development or lack of opinion on that matter.

Table 1

Living in accordance with the principles of sustainable development in the context of EU membership ( $\%$ of the sum of the line)

\begin{tabular}{|l|c|c|c|c|c|c|c|}
\hline No & Specification & $\begin{array}{c}\text { Definitely } \\
\text { yes }\end{array}$ & $\begin{array}{c}\text { Rather } \\
\text { yes }\end{array}$ & $\begin{array}{c}\text { Neither } \\
\text { no, nor } \\
\text { yes }\end{array}$ & $\begin{array}{c}\text { Rather } \\
\text { not }\end{array}$ & $\begin{array}{c}\text { Definitely } \\
\text { not }\end{array}$ & $\begin{array}{c}\text { I have } \\
\text { No opinion }\end{array}$ \\
\hline $\mathbf{1 .}$ & $\begin{array}{c}\text { Countries of the } \\
\text { EU } 15\end{array}$ & 18.4 & 47.6 & 21.4 & 6.8 & 0.0 & 5.8 \\
\hline $\mathbf{2 .}$ & $\begin{array}{c}\text { Countries of the } \\
\text { EU } 28-15\end{array}$ & 7.4 & 29.8 & 31.2 & 9.1 & 1.7 & 20.9 \\
\hline $\mathbf{3 .}$ & $\begin{array}{c}\text { Countries outside } \\
\text { of the EU }\end{array}$ & 12.0 & 32.2 & 29.7 & 14.3 & 2.7 & 9.0 \\
\hline
\end{tabular}

Source: authors' work

Living in accordance with the principles of sustainable development was also related to the level of education: in all the groups of countries the percentage of positive answers ("definitely yes" and "rather yes") grew as the level of education increased (Table 2). Academic youth representing the countries of the $\mathrm{EU}_{15}$ stood out - the percentage of the answers confirming living in accordance with the principles of sustainable development was markedly higher compared to the answers of the youth from the countries of the $\mathrm{EU}_{28-15}$ or countries outside of the EU. The effectiveness of the education 
designed to shape conscious attitudes among youth in the countries of the "old Union" was confirmed by the lack of the answer "definitely no" at all levels of education. Only among first-cycle students there was a small group of people who did not have an established opinion on the issue of living in accordance with the principles of sustainable development. The situation in the countries of the $\mathrm{EU}_{28-}$ 15 looked quite different. There, approximately every fifth surveyed student of first- and second-cycle studies declared lack of opinion, and every third - indifference towards sustainable development. Compared to this group, the students from the countries outside of the EU have shown significantly more sensitivity to the postulates of sustainable development.

\section{Living in accordance with the principles of sustainable development and level of education ( $\%$ of the sum of the column)}

\begin{tabular}{|c|c|c|c|c|c|c|c|c|c|c|}
\hline \multirow{2}{*}{ No } & \multirow[t]{2}{*}{ Specification } & \multicolumn{3}{|c|}{$\begin{array}{c}\text { Countries of the } \\
E_{15}\end{array}$} & \multicolumn{3}{|c|}{$\begin{array}{l}\text { Countries of the } \\
\qquad \mathbf{E U}_{28-15}\end{array}$} & \multicolumn{3}{|c|}{$\begin{array}{c}\text { Countries outside } \\
\text { of the EU }\end{array}$} \\
\hline & & $\mathbf{I}$ & II & III & $\mathbf{I}$ & II & III & $\mathbf{I}$ & II & III \\
\hline 1. & Definitely yes & 12.3 & 26.1 & 57.1 & 7.2 & 6.9 & 15.8 & 10.8 & 18.6 & 0.0 \\
\hline 2. & Rather yes & 45.2 & 60.9 & 28.6 & 27.3 & 33.3 & 47.4 & 28.4 & 42.4 & 66.7 \\
\hline 3. & Neither no, nor yes & 27.4 & 4.3 & 14.3 & 32.5 & 29.9 & 15.8 & 30.2 & 27.1 & 33.3 \\
\hline 4. & Rather not & 6.8 & 8.7 & 0.0 & 9.8 & 7.8 & 5.3 & 17.7 & 3.4 & 0.0 \\
\hline 5. & Definitely not & 0.0 & 0.0 & 0.0 & 2.1 & 0.5 & 5.3 & 3.0 & 1.7 & 0.0 \\
\hline 6. & I have No opinion & 8.2 & 0.0 & 0.0 & 21.0 & 21.6 & 10.5 & 9.9 & 6.8 & 0.0 \\
\hline
\end{tabular}

I - undergraduate/engineering studies; II - graduate studies; III - doctoral studies

Source: authors' work

Interesting were also the findings showing the attitudes towards sustainable development among academic youth from the European countries depending on their background and place of residence. The question arises whether residents of rural areas are more likely to be more sensitive to the issues of sustainable development due to more contact with the nature compared to urban residents. Or maybe it is rural residents who feel greater need for sustainable development and want to implement it because they perceive threats to the environment and the nuisances of living in urbanised areas? The authors are not familiar with findings of previous research that would allow them to take a clear position on that issue. Having said that it is worth reminding the experiences of the Chicago school - a current in empirical sociology that already the 1920s emphasised typically urban causes of social problems, such as overcrowded housing estates, high buildings and separation of residents from the nature, i.e. green parks, trees, garden squares or open areas (Wecławowicz G., 2003, Tkocz J., 2005). Later research seemed to confirm these observations: in housing estates with a lot of greenery the number of crimes was on average half of that in housing estates with fewer trees and less greenery. Living in a house surrounded by forests, meadows or in another natural environment contributed to improvement in children's perceptual abilities and generally improved their mental health. Thus, a well-preserved environment has not only an impact on a social subsystem. It is also of key importance to the economic subsystem (higher quality of life, better conditions for running an economic activity, increased interest in land and its prices, increased attractiveness in terms of tourism). Therefore, it seems that in rural areas - at least theoretically - sensitivity to the idea of sustainable development may be higher. However, in the research conducted by the authors, neither background (Table 3) nor current place of residence (Table 4) of academic youth had a clear impact on respondents' declarations regarding living in accordance with the principles of sustainable development. 
Living in accordance with the principles of sustainable development and the respondent's background ( $\%$ of the sum of the line)

\begin{tabular}{|l|c|c|c|c|c|c|c|}
\hline No & Background & $\begin{array}{c}\text { Definitely } \\
\text { yes }\end{array}$ & $\begin{array}{c}\text { Rather } \\
\text { yes }\end{array}$ & $\begin{array}{c}\text { Neither } \\
\text { no, nor } \\
\text { yes }\end{array}$ & $\begin{array}{c}\text { Rather } \\
\text { not }\end{array}$ & $\begin{array}{c}\text { Definitely } \\
\text { not }\end{array}$ & $\begin{array}{c}\text { I have } \\
\text { No opinion }\end{array}$ \\
\hline 1. & City & 9.9 & 32.2 & 29.3 & 9.9 & 2.2 & 16.5 \\
\hline 2. & Rural area & 9.5 & 32.4 & 30.9 & 11.3 & 0.9 & 15.0 \\
\hline
\end{tabular}

Source: authors' work

Living in accordance with the principles of sustainable development and the respondent's place of residence ( $\%$ sum of the line)

\begin{tabular}{|l|c|c|c|c|c|c|c|}
\hline No & $\begin{array}{c}\text { Place of } \\
\text { residence }\end{array}$ & $\begin{array}{c}\text { Definitely } \\
\text { yes }\end{array}$ & $\begin{array}{c}\text { Rather } \\
\text { yes }\end{array}$ & $\begin{array}{c}\text { Neither } \\
\text { no, nor } \\
\text { yes }\end{array}$ & $\begin{array}{c}\text { Rather } \\
\text { not }\end{array}$ & $\begin{array}{c}\text { Definitely } \\
\text { not }\end{array}$ & $\begin{array}{c}\text { I have } \\
\text { No opinion }\end{array}$ \\
\hline 1. & City & 10.0 & 32.0 & 30.3 & 10.1 & 1.8 & 15.8 \\
\hline 2. & Rural area & 8.9 & 33.3 & 27.7 & 11.4 & 2.0 & 16.8 \\
\hline
\end{tabular}

Source: authors' work

Analysing the survey results showing the attitudes to and opinions on living in accordance with the principles of sustainable development depending on respondents' gender, No significant differences in the answers have been found. Generally, women studying both in EU member states and outside of the EU gave similar responses to men. It can be, however, noted that women slightly more often declared responses confirming behaviour consistent with the idea of sustainable development, and less often those contradicting such behaviour. However, they more often indicated lack of knowledge and lack of opinion in this area (Table 5).

Living in accordance with the principles of sustainable development by the criterion of the respondent's gender (\%)

\begin{tabular}{|l|c|c|c|c|c|c|c|}
\hline No & $\begin{array}{c}\text { Respondent's } \\
\text { gender }\end{array}$ & $\begin{array}{c}\text { Definitely } \\
\text { yes }\end{array}$ & $\begin{array}{c}\text { Rather } \\
\text { yes }\end{array}$ & $\begin{array}{c}\text { Neither } \\
\text { No nor } \\
\text { yes }\end{array}$ & $\begin{array}{c}\text { Rather } \\
\text { not }\end{array}$ & $\begin{array}{c}\text { Definitely } \\
\text { not }\end{array}$ & $\begin{array}{c}\text { I have } \\
\text { No opinion }\end{array}$ \\
\hline 1. & Female & 9.7 & 33.0 & 29.5 & 8.7 & 1.6 & 17.6 \\
\hline 2. & Male & 9.9 & 31.2 & 30.3 & 12.7 & 2.1 & 13.9 \\
\hline
\end{tabular}

Source: authors' work

\section{Conclusions}

The verbalised concept of sustainable development still presents itself better in theory than in practice. A range of awareness-related, political and economic barriers stop actual efforts to implement this idea. What is needed is first of all good will on the part of intellectuals, politicians, economic strategists and ruling circles at all levels, from international organisations, to governments and economies of the individual countries, to local and regional authorities. There is also a need for continuous intellectual development leading to a better understanding of this concept and development in people of awareness and responsibility for the living environment and further development of civilisation.

Undoubtedly, education plays a very important role in the process of implementing sustainable development. The surveys have shown that the youth receiving university level education in the countries of the "old Union" was markedly more sensitive to the need to live in accordance with the principles of sustainable development.

Encouraging was the fact that as the level of education increased, awareness of sustainable development grew. However, youth's attitudes may be a cause for optimism only in the case of students of doctoral studies, which are undertaken by only a small percentage of young people. 


\section{Bibliography}

1. Agenda Zrownowazonego Rozwoju 2030 (Sustainable Development Agenda 2030). (2015). Retrieved: https://www.polskapomoc.gov.pl/Agenda,Zrownowazonego,Rozwoju,2030,2370.html. Access: 18.01.2019.

2. Boc, J., Nowacki, K., Samborska-Boc, E. (2004). Ochrona srodowiska (Environmental protection). Wydawnictwo Kolonia Limited, Wroclaw, p. 60.

3. Borys, T. (2011). Zrownowazony rozwoj - jak rozpoznac lad zintegrowany (Sustainable Development - How to Recognize Integrated Order), Problems of sustainable development. No. 2, vol. 6, pp. 75-81.

4. Dacko, M., Plonka, A. (2017). Idea rozwoju zrownowazonego w opiniach i postawach rolnikow (Idea of sustainable development in the opinions and attitudes of farmers). Roczniki Naukowe Stowrzyszenia Ekonomistow Rolnictwa i Agrobiznesu XIX (1), pp. 38-43.

5. Dacko, M., Plonka, A., Prus, p. (2018). Mlodziez akademicka wzgledem idei rozwoju zrownowazonego (Youth Academic and the Idea of Sustainable Development), Roczniki Naukowe Stowrzyszenia Ekonomistow Rolnictwa i Agrobiznesu, XX(1), pp. 24-29.

6. Ekspertyza dotyczaca edukacji dla zrownowazonego rozwoju w Polsce (Expertise on education for sustainable development in Poland) (2012). Ministerstwo Srodowiska (Ministry of the Environment).

7. Hull, Z. (1992). Filozoficzne podstawy ekorozwoju (The Philosophical conditioning of sustainable development), Zeszyty Problemowe Postepow Nauk Rolniczych, 401, pp. 27-40.

8. Kielczewski, D., Poskrobko T. (2009). Dydaktyka ekonomii zrownowazonego rozwoju (Teaching the economy of sustainable development), Problemy Ekologii, 13(5), pp. 238-239.

9. Kielczewski, D., Poskrobko T. (2010). Dydaktyka ekonomii zrownowazonego rozwoju (Teaching the economy of sustainable development) (in:) Poskrobko B., Ekonomia zrownowazonego rozwoju. Zarys problemow badawczych i dydaktyki (The economics of sustainable development. Outline of research and teaching issues). Wyzsza Szkola Ekonomiczna, Bialystok, pp. 95-100.

10. Kowal, J. 1998. Metody statystyczne $w$ badaniach sondazowych rynku (Statistical methods in researches of market). Wydawnictwo PWN, Warszawa.

11. Lorek, A. (2013). Edukacja dla zrownowazonego rozwoju na przykladzie Uniwersytetu Ekonomicznego w Katowicach (Education for Sustainable Development at the University of Economics in Katowice), Studia Ekonomiczne. Uniwersytet Ekonomiczny w Katowicach, 131, pp. 23-31.

12. Matysiak, A., Strus, M. (2015). Paradygmat rozwoju zrownowazonego (Paradigma of sustainable development), Studia Ekonomiczne. Zeszyty Naukowe Uniwersytetu Ekonomicznego w Katowicach, 213, pp. 11-22.

13. Piontek, B. (2002). Koncepcja rozwoju zrownowazonego i trwalego Polski (The concept of sustainable and durable Poland development). Wydawnictwo PWN, Warszawa, p. 51.

14. Poczta-Wajda, A., Sapa, A. (2017). Paradygmat rozwoju zrownowazonego - ujecie krytyczne (The paradigm of sustainable development: a critical approach), Progress in Economic Sciences, 4, pp. 131-142.

15. Poskrobko, B. (2013). Paradygmat zrownowazonego rozwoju jako wiodacy kanon w badaniu nowych obszarow ekonomii (The Paradigm of Sustainable Development as the Leading Standard in the Research on New Spheres of Economics), Ekonomia i Srodowisko, 3(46), pp. 10-24.

16.Skowronski, A. (2006). Zrownowazony rozwoj perspektywa dalszego postepu cywilizacyjnego (Sustainable development as the perspective of further civilisation development), Problemy ekorozwoju, No 2, vol. 1, pp. 47-57.

17. Strategia Edukacji dla Zrownowazonego Rozwoju (Education Strategy for Sustainable Development) (2008). United Nations Economic Commission for Europe. Ministry of the Environment, Warszawa.

18. Ustawa z dnia 27 kwietnia 2001 r. Prawo ochrony srodowiska (Act of 27 April 2001. Environment protection act) (2001 r.). Retrieved: http://prawo.sejm.gov.pl/isap.nsf/DocDetails.xsp?id=WDU20010620627 Access: 18.01.2019.

19. Wecławowicz, G. (2003). Geografia spoleczna miast. Zroznicowania spoleczno-przestrzenne (Social geography of cities. Socio-spatial diversity). Wydawnictwo PWN, Warszawa, pp. 1-222.

20.Tkocz, J. (2005). Podstawy geografii spoleczno-ekonomicznej (Basics of socio-economic geography). Wydawnictwo Uniwersytetu Slaskiego, Katowice, pp. 1-268. 